\title{
On Sraffa, post-Keynesian theories of pricing and capitalist competition: Some observations
}

\author{
Stephanie Blankenburg*
}

\begin{abstract}
The paper explores the implications of the I920s sost controversy for heterodox economic theory (here limited to post-Keynesian and Sraffian analysis). It argues that neither neoclassical nor heterodox theories have found viable solutions to the basic dilemma posed by the cost controversy, namely how to reconcile a general theory of price with that of growth and accumulation. The a priori commitment of neoclassical theory to a symmetric theory of exchange and production means that the impasses met by Walrasian general equilibrium theory and by the New Endogenous Growth Theory cannot be resolved, while also preserving explanatory power. For the case of post-Keynesian and Sraffian theory, it is suggested that, while a claim to "a general theory of everything" is also unsustainable, a reconsideration of the methodological roots of Sraffa's own analysis and of core aspects of classical theories of competition, might open an avenue to providing an empirically relevant heterodox theory of contemporary corporate capitalism.
\end{abstract}

JEL classifications: B20, B50, Lo

Keywords: cost controversy, Sraffa, post-Keynesian theory of pricing, classical theory of competition

* School of Oriental and African Studies (SOAS), University of London, UK.

Correspondence Address:

Stephanie Blankenburg, Department of Economics, School of Oriental and African Studies, University of London, Thornhaugh Street, London WCIH oXG, UK, e-mail: sbi23@soas.ac.uk.

Received Io July 20I0, accepted 25 November 2010

C INTERVENTION 8 (I), 20II, I83-200 


\section{Introduction}

Geoff Harcourt's role in promoting and developing heterodox economic thought has been so important that it prompted a Festschrift of no less than three volumes, published by P. Arestis, G. Palma and M. Sawyer (1996, 1997) and by C. Sardoni and P. Kriesler (1999), with contributions by over hundred economists on topics as wide-ranging as the capital theory controversies, the history of economic analysis, markets, unemployment, progressive economic policy and post-Keynesian economics. As one of Geoff Harcourt's many students, I have greatly benefited, not only from his inexhaustible knowledge of and contribution to (Cambridge) economics, but first and foremost from his selfless dedication to the younger generation. Harcourt's socio-political engagement with the present, together with his openminded and deep understanding of conflicting intellectual agendas, have enabled him to look beyond the sometimes rather small-minded world of professional academics. It has also enabled him to be a truly great teacher who knows how to mobilise his students' abilities and to ensure that they will scarry the flame, precisely because he encourages debate and constructive dissent. This is a very rare ability, yet one that is more vital than any other to ensure that those schools of thought which find themselves in opposition to the mainstream wisdoms and powers of the day will survive.

This paper takes up a topic on which, some years ago, Geoff Harcourt invited my co-operation: A re-assessment of the relevance of the scost controversy of the I920s for contemporary economic theorising. At the time we (Blankenburg/Harcourt 2007) focused on the New Endogenous Growth Theory and its recourse to externalities to minimise the potential damage done by dynamic increasing returns to scale to the so-called `Marshallian symmetric theory of prices and distribution. The main purpose of this paper is to extend this analysis to modern heterodox economic theorising. Geoff Harcourt's contribution to heterodox theorising has been focused on post-Keynesian and Sraffian theory, and this paper thus stays within this area of economic heterodoxy. Section 2 provides a brief overview over the main arguments made during the 'cost controversy،. Section 3 reviews the failure of postMarshallian neoclassical theory to resolve the issues raised by the critique of /Marshallian partial equilibrium analysis. Section 4 turns to post-Keynesian and Sraffian theories, arguing that while these have met with important impasses in reconciling Sraffa's asymmetric theory of prices, distribution and reproduction with a dynamic analysis of (contemporary) capitalism, interesting avenues remain to be explored, in particular with regard to theories of competition. Section 5 concludes.

\section{The cost-controversy: A brief re-cap}

The rcost controversy เ took place in the pages of the Economic Journal between 1922 and 1930. At its the heart was the logical and empirical viability of so-called Marshallian partial equilibrium analysis and, in particular, Marshall's internal-external economies‘ - as reinterpreted by self-proclaimed followers, such as Pigou and Robertson-, or the suggestion that 
variable returns could be made compatible with the determination of prices by competitive market forces and exchange alone. If the >Marshallian` argument held true, the sphere of production - of the organisation of industry - was not autonomous from that of exchange, excluding therefore the assumption of increasing returns to scale. If it did not, market forces alone could explain neither production nor, consequently, dynamics. Once the dust had settled, three contributions stood out among the long list of distinguished contributors to the debate: Sraffa (1926), Young (1928) and Shove's contribution to the final symposium on the controversy (Keynes I930: 92-II6).

Sraffa (I926) - together with Sraffa (I925 [1998]), the longer Italian version of the first part of his contribution to the scost controversy< - demonstrated that the partial equilibrium analysis of competitive value, and of the perfectly competitive firm, cannot logically accommodate an industry supply curve with variable costs beyond two empirically irrelevant cases. For Marshall's (long-period) industry supply curve to be logically consistent, he must exclude all output changes from the analysis that give rise to variable returns to scale with a direct effect on the technical coefficients of other industries, and therefore on prices and distribution. The choice then is between assuming constant marginal returns, incompatible with a symmetric theory of value, or abandoning partial equilibrium analysis in favour of a theory that takes explicit account of inter-industry cost-output interdependencies. For Sraffa, the root cause of the symmetry assumption between demand and supply forces was the failure to take account of the objective contents and context in which abstract concepts originate: Diminishing returns belonged to the sphere of distribution (rather than relative prices), and increasing returns to that of "general economic progress" (rather than an »increase in the scale of production «) (Sraffa 1926: 557, I925 [1998]: 324). The two could only be forced into the corset of a symmetric theory of demand and supply by reducing its empirical validity to insignificance:

"In particular, it remains to be seen whether the fundamentum divisionis is formed by objective circumstances inherent in the various industries, or instead, is dependent on the point of view of the person acting as observer; or to put it another way, whether the increasing and decreasing costs are nothing other than different aspects of one and the same thing that can occur at the same time, for the same industry, so that an industry can be classified arbitrarily in one or the other category according to the definition of industry that is considered preferable for each particular problem, and according to whether long or short periods are considered." (Sraffa 1925: 324, emphasis added) ${ }^{\mathrm{I}}$

I On 28 November 1927 Sraffa noted: "Now that sthe period (i.e. both the duration of production and the relevant period for determining quasi rent and such things and incr[easing]. or dim[inishing] ret[urns]) is for me one well defined for each industry (i.e. Keynes' $t$ ), it seems to me incredible that Marshall could think of /long and short periods as applying to the same industry at the same time: how could he think that there was such a thing as stwo different simultaneous times? His process of thought was obviously this: this or that effect will follow according as we are considering long or short periods (or we allow long or short time)<. The poor man thought that he himself was going to decide arbitrarily (or to give the permission!) how long a time the cause will take to bring about its effect! Of course he 
Young (1928) provided an analysis of increasing returns to scale that, while inspired by Adam Smith as well as by Marshall's notion of the sources of increasing returns, was another nail in the coffin of Marshallian partial analysis. Not only did Young reject Marshall's view that external economies arise within an industry, insisting instead that "industrial operations be viewed as an interrelated whole» (Young 1928: 539). But whereas Marshall explicitly excludes "any economies that may result from substantive new inventions " (Marshall 1920 [1949]: 460), thereby leaving open the door to a static interpretation of increasing returns (i.e. marginal increasing returns to scale arising from equi-proportional factor changes and fixed input costs), Young makes technological change one of the corner stones of his analysis of dynamic increasing returns. Emphasizing the complementarity relation between factors of production, Young (1928) replaces the principle of partial factor variation with that of the cumulative nature of economic progress: Increasing returns to scale, realised through lower costs resulting from the progressive division and specialisation of industries, are of a dynamic and inter-sectoral nature, compatible with piecemeal and radical technological change, variable input costs and non-proportional factor changes.

Shove managed to shore up a last-ditch defence of Marshallian partial analysis that despite its sophistication remained wedded to the inherently vague concept of the representative firm ‘ to bridge the gap between static and dynamic analysis: As a longperiod equilibrium concept, the representative firm ‘ could accommodate the development of differential entrepreneurial skills, changing luck, and variations in firm's rates of profit as - roughly - an inverse U-shaped function of some form of scollective learning over time, so long as aggregate output is unchanged and »resources within the industry [...] are distributed between the firms in the most profitable way" (Shove in Keynes 1930: 96). Importantly, there could then also be what we would now call path-dependent multiple equilibria. And, differently from Marshall's original trees of the forest analogy, firms could survive indefinitely. Obviously, this at least hints at ways of avoiding aggregation problems, but it remained unclear how exactly a competitive industry equilibrium of any kind would actually emerge under these conditions or, indeed, why sdynamicss should be limited to the firm-level factors listed cum path dependency.

Sraffa left no doubt that, as a result of the rcost controversy,, "it is Marshall's theory that should be discarded (Sraffa in Keynes 1930: 93). In 1926, he had already pointed to the two main routes out of the conundrum: The first - a theory of imperfect competition came with a warning attached: Firms and industries cannot be grouped along a continuous spectrum of competitive conditions, ranging from perfect competition to pure monopoly, since "the cumulative action of slight obstacles to competition produces on prices effects which approximate to those of monopoly« (Sraffa 1926: 549). It is not possible to analyse

thought of time as continuous and therefore whenever he had to take it into consideration he had to consider an arbitrary segment of it. He did not realise that sthe period i.e. the duration of production is an objective magnitude." (Sraffa Papers $\mathrm{D}_{3} / \mathrm{I} 2 / \mathrm{II}$, emphasis in the original) The Sraffa Archive is kept in the Wren Library at Trinity College, Cambridge, UK. References to Sraffa's unpublished notes follow the catalogue prepared by members of staff at the Wren Library. 
general industry prices, but only the supply and demand conditions of each individual firm. The second route is only hinted at in the closing paragraphs of Sraffa's (I926: 550) contribution, namely to replace partial equilibrium analysis with a general theory of costoutput interdependencies that studies

"the process of diffusion of profits throughout the various stages of production and of the process of forming a normal level of profits throughout all the industries of a country«.

\section{The (unsuccessful) neoclassical response}

For neoclassical theory, the core challenge arising from the ‘cost controversy` was to safeguard the symmetric theory of exchange and production. The >Marshallian route was blocked. The intellectual trajectory that followed was not, of course, guided by a unilinear concern to 'get over the Marshallians`. In essence and retrospect, though, it seems fair to point out that by the end of the I930s, Hick's Value and Capital had paved the way to an alternative that took recourse to Walras rather than the >Marshalliansı. Prevailing until the mid I970s, this was based on the concept of general economic equilibrium and a symmetric theory of value on neoclassical terms of what constitutes science, economics and its relationship with other social sciences. On these terms, a systematic integration of increasing returns to scale with a general theory of growth had to wait until the advent of the New Endogenous Growth Theory (NEGT). By the mid I970s, the failure of General Equilibrium Theory (GET) to provide a theory of tâtonnement, and thus of competitive price formation, had gradually become clear: The most important impasses include: (a) Franklin Fisher's (1973, 1983) demonstration of the impossibility of proving the stability of competitive Walrasian equilibria without recourse to totally implausible assumptions, such as Hahn's gross substitutability hypothesis; (b) the failure to provide microeconomic foundations for competitive situations that allow the transition from individual to global demand and supply functions, in particular the Sonnenschein-Mantel-Debreu proof of the arbitrariness of well-behaved aggregate excess demands (Sonnenschein 1972, Debreu I974); (c) Hahn's (I977) demonstration that, once information constraints (conjectures or beliefs) are included in the 'givens`, the best GET can attain are sconjectural equilibria whose existence and uniqueness are problematic; and (d) the extremely limiting assumptions required to prove the existence of general equilibrium under imperfect competition (e.g. Laffond/Laroque 1976). And whilst intertemporal general equilibrium models (e.g. Bliss 1975) could avoid the results of the Cambridge capital theory controversies, the rather elevated price to pay was to abandon the relative scarcity theory of distribution (Cohen/Harcourt 2003: 207). The NEGT, alongside other branches of the ınew classical macroeconomics`, ignored these impasses and adopted the intertemporalutility-maximising-representative-agent microeconomics, harshly criticised by Hahn and Solow (I997) for plundering the tool box of normative optimal growth theory for purposes of analysing actual economies. Kirman (1989, I992) had already taken the new so-called microfoundations of macroeconomics` to task for avoiding the aggregation problem and 
failing to address the question of "how and why a sector of society or society itself organises itself in such a way as to behave like an individual, if indeed it does (Kirman I989: 137). Or, as Fine (2000: 248) put it for the NEGT more specifically, "the literature takes a microeconomic theory and simply interprets it as (long-run) macroeconomics«. Equipped with what Joan Robinson might have called `Bastard GET`, the NEGT imported insights from a wide range of economic theory and policy concerns, that had been largely excluded from conventional neoclassical (Solovian and optimal) transition analysis, such as different patterns of innovation and competition, the role of institutions, different income distribution and trade regimes, and disaggregated production structures. The main price to be paid for forcing the analysis of growth dynamics into the straightjacket of the representative agent framework, such that any factor that can plausibly be construed to influence agents' decisions about present versus future consumption and saving will affect not only the allocation of given resources but also future productivity, has been the loss of explanatory power at the macro-level:

»On the one hand, limited generalisations of basic assumptions suffice to generate a wealth of outcomes. On the other, models become intractable beyond the point of the most simplified models of the economy." (Fine 2000: 250)

In response, the NEGT has looked, not towards historically- and inter-disciplinarilyinformed studies of the determinants of the institutional and technological growth factors it has sendogenised،, but to econometrics, and cross-country regressions in particular (e.g. Sala-iMartin 1997). An important corollary of the NEGT's a priori commitment to a symmetric theory of exchange and production, certainly from the perspective of the ‘cost controversy‘, is its inadequate treatment of increasing returns to scale. Much as, analytically, the NEGT tackles complex dynamics, such as for instance cyclical growth, its conceptual grasp of real growth dynamics remains poor. At its core, the NEGT conceptualises growth dynamics in terms of market imperfections arising mainly from the contemporary knowledge-driven nature of technical change and productivity increases (Romer 1986 and I990, Grossman/ Helpman 1991, Aghion/Howitt 1998). This entails the explanation of increasing returns to scale in terms of externalities essentially arising from indivisibilities in the production of knowledge. Whichever model of imperfect competition is adopted to address the presence of indivisibilities - horizontal innovation through product differentiation à la ChamberlinTriffin (cum Dixit-Stiglitz), or neo-Schumpeterian vertical innovation through sequential obsolence and >creative destruction - the externalities that cause increasing returns to scale are a static comparative measure of divergences between private and social costs. This reduction of increasing returns to indivisibilities falls short of Marshall's understanding of external economies as arising "from an increase in the scale of production" and, thus, "dependent on the general development of the industry" (Marshall I920 [1949]: 262), but even more so of the Young-Kaldor notion of increasing returns (Blankenburg/Harcourt 2007: 57-60). In the ‘Appendix on Indivisibilities and Increasing Returns` to The Irrelevance of Equilibrium Economics, Kaldor (1972 [1989]: 393-398) refutes Koopmans's (1957) view that the accommodation of increasing returns to scale within a symmetric theory of production and exchange is a matter of mathematical advances, arguing that 
" $[$ s]ince $[. .$.$] the demand for any particular product or group of products is a reflection$ of the level of production of other products, this means that any re-allocation of resources which enlarges the range of feasible activities comes to the same as an routward shift in the production frontier. The problem then becomes not just one of solving the mathematical difficulties`, resulting from discontinuities but the much broader one of replacing the sequilibrium approach « with some, as yet unexplored, alternative that makes use of a different conceptual framework." (Kaldor 1972 [1989]: 397-398)

More clearly than Marshall, Kaldor and Young associate increasing returns, not with market imperfections and imperfect competition, but with the potentially self-perpetuating, cumulative interplay between increases in demand, induced by increases in supply, and increases in supply, induced by increases in demand, throughout the economy: Decreasing costs are not, in the first place, the result of average variable costs falling more rapidly than average fixed costs increase, but of a restless process of cumulative accumulation that responds to a unity elasticity of demand with respect to overall output, in the long period, and at the same time keeps this demand alive by absorbing cost-reducing technical progress in the process (Young I990: 54). As for Marx, so for Young and Kaldor the driving force of this process of reciprocal demand is competition between capitalists. Far from implying a restriction on competition, dynamic increasing returns would fail to materialise were it not for the ultimate pervasiveness and forcefulness of the competitive drive of those in a position to exploit the sinsatiability` of demand. Whether this competition predominantly entails product or process differentiation is a question of the elasticity of demand. If demand for a product becomes inelastic, resources and purchasing power are released for the production of other items. There is no a priori tension between variety, (firm and market) size and economic growth: A larger overall market size leads to a higher degree of specialisation (and a higher rate of growth) across a larger number of more highly specialised firms and industries that can be big or small, but that will remain part of an (uneven) process of overall expansion in which cost reductions are being passed on to consumers through lower prices, better quality or more variety. If this process of growth begetting growth (rather than of sknowledge formation racing against diminishing returns to (physical) capital) is constitutive of increasing returns to scale, the sole imaginable limitation to this process of self-perpetuating expansion is necessarily of an institutional nature.

If neoclassical theory has failed to produce a general theory of prices and of growth that can accommodate dynamic (Young-cum-Kaldor type) increasing returns to scale, it is not surprising that some branches of neoclassical theory have given up altogether on establishing a general theory, and have adopted an alternative - game-theoretic - microfoundation within self-contained partial analysis. A case in point is the modern neoclassical theory of imperfect competition and oligopolistic pricing (e.g. Vives 200I). As has been pointed out by many commentators (e.g. Sylos Labini 1969: 46-47, Sutton I990), this has not alleviated the problem of an under-determination of model outcomes, derived from sheer endless possibilities to generate new hypotheses about >conjectural variations achieved within the confines of game-theoretic partial equilibrium analyses of imperfect 
competition, broadly considered, continue to rest on implausible assumptions of different types: Some, such as the assumption of common knowledge and rationality, imply that agents share a common model of the world that they know to be true because it can be assumed, on grounds not specified, that all agents share the same type of rationality, know all rules of the game and have complete information on possible game outcomes. Others, such as the assumption of independence between ,framing and pay-offs and of reducativer individual behaviour, are necessary to ensure the existence of a dynamic path toward a stable equilibrium, but have been recognised as far too demanding to yield explanatory power (e.g. Walliser 2006).

\section{The (ambiguous) beterodox reaction}

But how well have heterodox (post-Keynesian and Sraffian) approaches fared, in their turn, in reconciling price and growth theory? As mentioned, Kaldor (1972 [1989]) does, of course, provide an in-depth treatment of Youngian dynamic increasing returns to scale. As he points out, the main element absent from Young's original presentation is Keynesian induced investment that operates through intermediary buffers in competitive primary goods markets and directly through increases in demand in imperfectly competitive commodity markets (Kaldor 1972 [1989]: 389-390). Kaldor is, however, fully aware of open challenges arising from » this marriage of the Smith-Young doctrines on increasing returns with the Keynesian doctrine of effective demand " (Kaldor 1972 [1989]: 39I), in particular the fact that this lacks (or remains disconnected from) a theory of competition and prices. Thus he argues that

wit is evident that the co-existence of increasing returns and competition - emphasised by Young and also by Marx, but wholly excluded from the axiomatic framework of Walrasian economics - is a very prominent feature of de-centralised economic systems but the manner of functioning of which is still largely unchartered territory for the economist. We have no clear idea of how competition works in circumstances where each producer faces a limited market as regards sales and yet a highly competitive market as regards price.« (Kaldor 1972 [1989]: 392)

Kaldor (1985: 3I-56) provides some general pointers of what to consider in the study of price formation and competition in modern industrial economics, but mostly emphasises the need for further research. There are, of course, two principal approaches to heterodox price theory whose potential compatibility with Kaldorian cumulative growth theory (e.g. Setterfield 1997, Toner 1999) remains unclear: Sraffa's (1960) rasymmetric theory of prices, distribution and reproduction, and post-Keynesian theories of pricing. Not unlike tâtonnement for neoclassical GET, the analysis of gravitation dynamics has posed problems for Sraffian (general and asymmetric) price theory (Arena/Torre 1986, Steedman 1990). The dominant approach (e.g. Garegnani 1976 and 1978), has focused on the classical theory of the equalization of sector profit rates and on the question of the stability of production prices within a framework of the comparative study of long-period positions. This has entailed 
a number of strict limitations on the analysis, such as a complete dichotomy of the long and the short period, the frequent assumption of constant returns to scale and an exclusive reliance on intertemporal linear dynamics that depict gravitation as a gradual and smooth process of the reduction and eventual elimination of accidental deviations (disequilibria) from an entirely given natural (market clearing) state whose quantities are "already fixed, i.e. determined in another part of the theory« (Garegnani 1976: 4I). Some form of rational or perfect expectations about technical progress and future prices of fixed capital must also be assumed (Garegnani I979: I85, Lavoie I992: 147).

Arena et al. (1990) have argued for a less restrictive interpretations of gravitation dynamics consistent with Sraffa (I960). They explore the question of the formation of production prices (rather than primarily their stability) and adopt sequential non-linear dynamics extending the Sraffian framework of annual production cycles with an annual market. This implies abandoning the dichotomy between long and short period and replacing gravitation by more complex and less stable processes that describe interactions between a variable long-term trajectory and short-term adjustment. Gravitation no longer refers to the convergence of market toward production prices, but of production or cost-based prices (that may or may not be market-clearing) toward natural production prices` (Arena/Torre 1986: 69). This makes it possible to introduce different assumptions about returns to scale (Steedman I990: 7I) and to take account of radical technical progress and innovation. Similarly, differential rates of profit due to oligopolistic conditions (e.g. Sylos Labini I971: 270, Semmler 1984) as well as more complex aspects of economic interaction, such as the role of speculation, the existence of inventories, non-market bargaining and price rigidities (Arena et al. I990: 289-303) can now be considered. The sprices to be paid is that, rather than a

"unique canonical model of the market, analogous to the Walrasian one [...] [a] typology of markets may be introduced and made precise, according to specific institutional contexts." (Arena et al. 1990: 289)

As a consequence, gravitation may »be impossible to obtain, and it may appear under very different forms of dynamics" (ibidem). Arena et al. (I990: 304-305) argue that, rather than constituting a disadvantage, this allows us "to understand that classical dynamics may be a more important and interesting topic than gravitation processes", and to take account of »the whole range of classical dynamics". This view resonates with Pasinetti's conceptual argument, in a different context, that while the foundations provided by Sraffa (1960) are incompatible with the marginal theory of income distribution, they are compatible with a range of other theories of income distribution, and not a priori with only one specific such theory (Pasinetti I988: 136). Clifton (1977) makes a similar point in regard to competition theory arguing that

"[a]lthough the general price system in Production of Commodities utilises a concept of competition which results in a tendency toward a uniform rate of profit, that concept is entirely distinct from perfect competition. But it is never made explicit by Sraffa. There is no concept of the competitive firm in Sraffa's system". (Clifton 1977: 138) 
Instead, for Clifton, Sraffa's focus on the relation between, on the one hand, the existence and distribution of an economic surplus and, on the other, the problem of price determination implies

"that competitive conditions in Sraffa's price system refer to an objective tendency produced by rivalry among firms in their quest for growth, not - as in the theory of perfect competition - to an equilibrium distinguished by an optimum size of firm and by the absence of any and all such rivalry« (Clifton 1977: 14I).

Similarly, neoclassical imperfect competition that retains the ideal of perfect competition as a benchmark notion and associates large firm size with lower degrees of competition and rivalry, is incompatible with Sraffa's at least indirect concern with growth and therefore investment, rather than market behaviour. By contrast, a range of objective theories of competition that set out from the changing historical realities of the intensifying competitive dynamics of capitalist growth and development over time are compatible with Sraffa's system:

"The competitive firm in Sraffa's system is the modern corporation, not the atomistic firm of the neoclassical theory of perfect competition. The conditions of free capital mobility which permit maximum flexibility and intensity for an independent unit of capital to directly search out the highest possible rate of return in the market are most closely approximated in the modern corporation." (Clifton 1977: 150)

Post-Keynesian models of industrial pricing certainly focus on power, growth and survival as the long-run objective of large price-setting corporations. Of the different cost-plus pricing procedures (Lavoie 1992: 94-I48, Sawyer 1995: 133-169, Lee 1998), full-cost or normal cost pricing (Eichner 1976 and 1986, Wood 1975, Harcourt/Kenyon 1976 [1982], Coutts et al. 1978) and target-return pricing (Lavoie I992: I3I-I33) have dominated postKeynesian approaches, in particular, if Kaleckian mark-up pricing is not, strictly, included under the label 'post-Keynesian. Eichner's (1976) `megacorp` and "the influential paper by Harcourt and Kenyon (1976) "(King 2002: I28) share a number of core assumptions, such as a srepresentative firm ‘ that is a large oligopolistic price leader, constant variable average and thus marginal costs up to the point of full capacity utilization, growth maximisation as the main firm objective, and the importance of retained earnings. Eichner's core contribution consists in the detailed analysis of the role of retained earnings for the behaviour of the 'megacorp under uncertainty and of the constraints on the generation of cash flow mainly in the form of the (consumer) substitution effect and the threat of potential market entry by rivals. Harcourt and Kenyon (1976 [1982]: 104) too, focus on the investment decision, but do so by "extending Salter's pioneering analysis of technical progress and the investment decision to a non-perfectly competitive setting «. Price-setting takes account of three different aspects of the investment decision: »the amount of extra capacity to be laid down in each period, the choice of technique and the method and cost of finance« (Harcourt/Kenyon 1976 [1982]: I22). A unique price is derived from the intersection of two sets of firm expectations, those that relate price to output to be catered for by new investment (the higher the expected price, the more easily old vintages of capital equipment can be used), and those that concern the flow 
of retained earnings over a current period for investment purposes given only one available best practicer technique at any one moment in time. This price equalises expected supply and demand, thus matching the necessary funds for the growth of productive capacities to demand conditions in the next period and the degree of utilisation of this capacity. Harcourt and Kenyon (1976) avoid one of the most criticised features of Eichner's `megacorp`, namely his recourse to the marginal efficiency of capital (or investment) to define the optimal growth of the average cash flow. More generally, Harcourt and Kenyon (I976), together with Wood (I975), provide a more precise analysis of the compatibility between oligopolistic firm strategies directed at capital accumulation and market expansion, while also providing a clearer account of firms' financial decision-making and of the profit-investment relationship (Arena 1992: I26-I28). Not surprisingly, Sraffians have pointed to a core weakness of the cost-plus approach to pricing, namely its focus on partial analysis. While these approaches explore important linkages between set prices, the level of profits, the finance available for investment, and thereby overall growth of output and future demand,

"the cost-plus theories [...] are a variant of the partial cost of production approach which Sraffa's Production of Commodities has superseded. By focusing on the individual firm in one industry, the cost-plus theories neglect those interactions among firms in the economic process as a whole which must be the basis for a general theory of price." (Clifton I977: I42-I43)

Steedman's (1992, 1993) attack on Kaleckian mark-up pricing models made a similar point, namely that the inappropriate partial approach to pricing and distribution neglected interindustry input-output relations as well as joint production. Steedman (I992: I4O) also pointed out that these models lacked a theory of the determination of prices and distribution in the long period. The (typically Marshallian) dichotomy between the long and the short period is also present in normal cost models and their use of average and marginal cost curves. This essentially leaves the determination of `normal variables, such as normal average costs, exogenous to the analysis, with hypotheses about the shape of normal cost curves necessarily based on ad hoc considerations of conventions or norms, rather than observed investment behaviour. Another Marshallian >relic revived by post-Keynesian theories of pricing has been the >representative firm . Kaldor (1985: 49), in revoking this concept in the context of a discussion of "how competition works", refers to a "group of firms « whose average behaviour, efficiency and productive abilities set the standard for the level and structure of prices in an industry, whether in tacit collusion or independently. It is certainly the Pigovian equilibrium firm and Triffin's (I940) >cleansing` of ‘the group from Chamberlin's theory of imperfect competition that are to be blamed for expunging even the slightest hint of competitive dynamics encapsulating the growth path of a firm from the Marshallian (including Shove's) concept of the `representative firm`. But the post-Keynesian `representative firm`, with its emphasis on 'normal industry expenses for a given aggregate volume of production, also seems to prefer the more static side of Marshall's (habitual) ambiguity in defining his srepresentative firm`. Whilst Kalecki (I97I) and Eichner (I976), amongst others, have stressed the need to take account of firm interdependencies in price formation, there seems to be 
insufficient notice taken of Young's (I928: 538) observation that " [w] ith the extension of the division of labour, the representative firm, like the industry of which it is a part, loses its identity«. Sawyer (I995: $156-158$ ) rightly points out that »insufficient attention is paid to competition and rivalry«, and that

"[m]any of the post Keynesian approaches have been rather static in the sense of taking the industrial structure (whether in terms of the degree of industrial concentration or in terms of an established price leader) as given and paying little regard to the process of change and in some versions appearing to ignore the pressures of competition on firms«.

There have been some constructive suggestions regarding the integration of mark-up pricing with Sraffian price theory (e.g. Mainwaring I992, Lavoie I992: I44-I48). Harcourt (I965) also already develops a corn model with a non-basic good that uses mark-up pricing for a shortrun analysis of income distribution and unemployment. Yet, most responses to Steedman's critique of mark-up pricing (Sawyer 1992, Kriesler 1992, Steindl 1993) take a rather defensive stance, stressing methodological differences between Sraffian and post-Keynesian (cum Kaleckian) analyses. Much of this appears to be premised on an identification of Sraffa's own theory with Neo-Ricardian gravitation theory, excluding alternative interpretations such as those discussed above (Arena/Torre 1986, Arena et al. I990, see also Harcourt I98I, Sylos Labini 1969 and I97I, Roncaglia 1978) that at least pave the way for the study of nonlinear inter-firm and inter-industry dynamics compatible with a different interpretation of Sraffa's asymmetric theory of prices, distribution and reproduction. In a similar vain, it seems surprising that the Andrews-Brunner approach to normal pricing (Andrews I949, I95I [I993], Brunner 1967) has been largely neglected by the post-Keynesian theory of pricing (e.g. Lee/ Earl I993: 406-422). This, too, is of course a partial approach, but it avoids, in its original formulation, the short/long period dichotomy and focuses on the long-term determinants of oligopolistic price formation based on `observed facts` (Brunner 1967: 33). Importantly, the latter include increasing returns to scale. As Arena (I992 and 2007) has argued, Sylos Labini's theory of oligopolistic competition can be regarded as a direct development of Andrews' and Brunner's theory of normal costs. ${ }^{2}$ Arena (2007) goes beyond the Bain-Modigliani-SylosLabini model of oligopolistic competition, and highlights the classical nature of competition advocated by Sylos Labini, founded on an objectivist understanding of the dynamic roles of barriers to entry and of demand, and set within a broader historical and institutionalist view of markets and market forms (e.g Corsi/Guarini 2009). In this view, which degree of capital concentration (and thus competition) is the most appropriate to promote technical and

2 See Sylos Labini's introduction to the revised edition of Oligopoly and Technical Progress, published in English in 1969: "I owe much to Philip Andrews, especially as regards the ideas formulated in the first part of this book [on oligopoly, S.B.] - much more, certainly, than might appear from occasional footnote references. In my view Andrews' book, Manufacturing Business, which appeared in 1949, was the first major organic contribution to what I have called the new theory of the firm. « (Sylos Labini I969: viii) 
organisational progress is a question of the type of market (standardised industrial production, differentiated industrial production, service production) rather than of a universal sideal model establishing a unique relationship between firm size, degree of competition and technical progress or efficiency, used as a benchmark. As in classical political economy, the core determinant of degrees of competition is not firm size but barriers to entry. These are not only a matter of strategic price-setting behaviours or entrepreneurial drive, but first and foremost of the technological and institutional determinants of specialisation. The existence of different technologies and different associated increasing returns to scale at any one point in time engenders the necessity of a choice of technology and of discontinuous technical progress, characterised by complementary technological factor relations. There is no »such thing as a long-run supply curve" (Sylos Labini 1969: 29), i.e. no smooth continuous spectrum along which one can group smaller to larger plants, a point also made by Sraffa (1926). Institutional factors also play their role: legal debate and regulation, economic policy-making and social strife, divisions and domination all make their mark on barriers to entry. These determinants of barriers to entry (as opposed to exclusive reference to subjective strategic considerations by individuals in charge of corporations as manager-owners) also mean that, differently from Andrews (1949), the long-period price may differ from production costs. The capture of market segments (demand) within an industry is largely a matter of building a loyal customer base, a point emphasised both by Andrews and in Brunner's sobserved facts` (Brunner 1967: 33), as well as in Kaldor's notion of ggoodwill (Kaldor 1985: 19-2I). Finally, market size, reaction and absorptive capacity (or demand elasticity) are not a matter of hypothetico-deductive constructions of aggregate individual utilities, but of empirical observation. The income and price elasticity of demand is empirical and finite, and thus observable by businessmen (Sylos Labini 1962: 37-38, Arena 2007: 49-50).

\section{Concluding observations}

One of Sraffa's preoccupations in the second half of the I920s was methodological. He was concerned with Marshall's theory of competitive value because of its roots in both marginalism and classical political economy. Marshall's disregard for the different historical roots of the laws of diminishing and increasing returns in an attempt to safeguard the symmetry of supply and demand was just one instance of a wider methodological divide: Marginalism proceeds on the basis of a priori functional relationships, postulated by the scientific observer on the basis of thought-experiments that produce facts to fit his or her imagination of the world. Classical political economy provides expost abstractions from real world phenomena in real historical time, the essence of which is amenable to measurement. For Sraffa, only the latter method is compatible with achieving explanatory power. Sraffa (I960) laid the foundations for an asymmetric theory of price under generalised capitalist conditions at one moment in real time for the most abstract case of a complete profit-wage dichotomy. A range of theories of distribution, competition and growth are compatible with this foundation, so long as they are logically consistent and the result of a realistic method. It is difficult to see how 
neoclassical theory, with its a priori commitment to a symmetric theory of exchange and production, can overcome the various impasses its attempt to build a general theory of prices and of growth has met, in terms both of internal logical consistency as well as explanatory power. Arguably, Sraffian gravitation and post-Keynesian pricing theory have been afflicted by similar methodological fallacies as those Sraffa criticised in Marshall and Marshallian partial analysis: Over-generalisation and a priori reasoning certainly has undermined the explanatory power of some Sraffian gravitation analysis; and some, if not all, post-Keynesian theories of pricing appear to offer little more than 'progressive Marshallian partial analysis. Yet, and differently from, broadly speaking, neoclassical analysis, Sraffian and post-Keynesian analyses of different features of capitalism, at different levels of abstraction, do not have to rely on a priori reasoning about imaginary functional relationships or >laws‘. Neither Sraffa nor (mostly) Keynes did. Building on Sraffa's (1960) foundational framework for an asymmetric theory of prices, reproduction and distribution may never yield a general theory of everything . Beyond a `core` analysis of capitalism, we may have to content ourselves with historically (and geographically) bounded typologies of different forms of capitalist accumulation patterns and their technological and institutional determinants. But the lack of a sunique canonical model is not the same thing as lack of explanatory power. It has been suggested here, that in particular a return to, and modernisation of, classical political economy theories of competition beyond gravitation dynamics, might be an important step towards a less fragmented heterodox realistic analysis of contemporary capitalism since »[a] ny economic theory of capitalism must include some concept of competition «(Clifton I977: I37). This might, inter alia, also help to close the growing gap between the post-Keynesian theory of the (representative) firm and the capitalist realities of global competition between transnational corporations.

\section{References}

Aghion, P., Howitt, P. (1998): Endogenous Growth Theory, Cambridge/Mass.: MIT Press. Andrews, P.W.S. (1949): Manufacturing Business, London: Macmillan.

Andrews, P.W.S. (I95I) [I993]: Industrial analysis in economics - with special references to Marshallian doctrine, in: Lee, F., Earl, P. (1993): The Economics of Competitive Enterprise. Selected Essays of P.W.S. Andrews, Cheltenham: Edward Elgar, I23-158.

Arena, R. (1992): Les théories du coût complet: vers un renouvellement du débat?, in: Économies et Sociétés, Série Oeconomia, I6(3), IOI-I34.

Arena, R. (2007): La théorie de l'oligopole de Sylos Labini: diversité des interprétations et prolongements possibles, in: Revue d'Economie Industrielle, II8(2), 37-54.

Arena, R., Froeschle, C., Torre, D. (1990): Gravitation theory: Two illustrative models, in: Political Economy. Studies in the Surplus Approach, 6(I-2), 287-308.

Arena, R., Torre, D. (1986): Approche sraffienne et théorie de la gravitation: une tentative de rapprochement, in: Économie Appliqué, 39(I), 6I-86. 
Arestis, P., Palma, G., Sawyer, M. (eds.) (1996): Capital Controversy, Post Keynesian Economics and the History of Economic Thought: Essays in Honour of Geoff Harcourt, Vol. I, New York/ London: Routledge.

Arestis, P., Palma, G., Sawyer, M. (eds.) (1997): Markets, Unemployment and Economic Policy: Essays in Honour of Geoff Harcourt, Vol. 2, New York/London: Routledge.

Blankenburg, S., Harcourt, G.C. (2007): The representative firm and increasing returns: Then and now, in: Arestis, P., Baddeley, M., McCombie, J.S.L. (eds.), Economic Growth. New Directions in Theory and Practice, Cheltenham: Edward Elgar Publishing, 44-64.

Bliss, C. J. (1975): Capital Theory and the Distribution of Income, Amsterdam and New York: Elsevier North-Holland.

Brunner, E. (1967): Prix concurrentiels, coûts normaux et stabilité de la branche, in: Revue d'Économie Politique, 77(I), 32-50.

Clapham, J.H. (1922): On empty boxes, in: Economic Journal, 32, 305-314.

Clifton, J.A. (1977): Competition and the evolution of the capitalist mode of production, in: Cambridge Journal of Economics, I, I37-I5I.

Cohen, A.J., Harcourt, G.C. (2003): Whatever happened to the Cambridge Capital Theory Controversies?, in: Journal of Economic Perspectives, I7(I), I99-2I4.

Corsi, M., Guarini, G. (2009): Growth and institutions in Sylos Labini's thoughts, Working Paper 1943I, MPRA Series, University of Munich, Germany, December.

Coutts, K., Godley, W., Nordhaus, W. (1978): Industrial Pricing in the UK, Cambridge: Cambridge University Press.

Debreu, G. (1974): Excess demand functions, in: Journal of Mathematical Economics, I, I5-2I.

Eichner, A.S. (1976): The Megacorp and Oligopoly: Micro Foundations of Macro Dynamics, Cambridge: Cambridge University Press.

Eichner, A.S. (1986): Toward a New Economics. Essays in Post-Keynesian and Institutionalist Theory, Basingstoke: Macmillan Press.

Fine, B. (2000): Endogenous growth theory: A critical assessment, in: Cambridge Journal of Economics, 24(2), 245-265.

Fisher, F. (1983): Disequilibrium Foundations of Equilibrium Economics, Cambridge: Cambridge University Press.

Fisher, F.M. (1973): Stability and competitive equilibrium in two models of search and individual price adjustment, in: Journal of Economic Theory, 6, 446-470.

Garegnani, P. (1976): On a change in the notion of equilibrium in recent work on value and distribution: a comment on Samuelson, in: Brown, M., Sato, K., Zarembka, P. (eds.), Essays in Modern Capital Theory, Amsterdam: North Holland, 25-45.

Garegnani, P. (1978): Notes on consumption, investment and effective demand I, in: Cambridge Journal of Economics, 2(4), 335-353.

Garegnani, P. (1979): Notes on consumption, investment and effective demand: A reply to Joan Robinson, in: Cambridge Journal of Economics, 3(2), I8I- I87.

Grossman, G., Helpman, E. (1991): Innovation and Growth in the Global Economy, Cambridge/ Mass.: MIT Press. 
Hahn, F. (1977): Exercise in conjectural equilibrium analysis, in: Scandinavian Journal of Economics, 79, 210-226.

Hahn, F., Solow, R. (1997): A critical essay on modern macroeconomic theory, Cambridge/Mass.: MIT Press.

Harcourt, G.C. (1965): A two-sector model of the distribution of income and the level of employment in the short-run, in: The Economic Record, 4I, IO3-I7.

Harcourt, G.C., Kenyon, P. (1976): Pricing and investment decisions, in: Kyklos, 29(3), 449-77, reprinted in: Harcourt, G.C. (1982), The Social Science Imperialists, London and New York: Routledge \& K. Paul.

Harcourt, G.C. (198I): Marshall, Sraffa and Keynes: Incompatible Bedfellows?, in: Eastern Economic Journal, 7 (I), 39-50.

Hicks, J. (1946 [1975]): Value and Capital: An inquiry into some Fundamental Principles of Economic Theory, $2^{\text {nd }}$ edition, Oxford: Oxford University Press.

Kaldor, N. (1972) [1989]: The irrelevance of equilibrium economics, in: Targetti, F., Thirwall, A. (eds.), The Essential Kaldor, London: Duckworth, 373-398.

Kaldor, N. (1985): Economics Without Equilibrium, New York: M.E. Sharpe.

Kalecki, M. (197I): Selected Essays on the Dynamics of the Capitalist Economy 1933-1970, Cambridge: Cambridge University Press.

Keynes, J.M. (1930) (ed.): Increasing returns and the representative firm. A symposium, (with contributions by D.H. Robertson, P. Sraffa and G.F. Shove), in: Economic Journal, 40, 79- II6.

King, J.E. (2002): A History of Post Keynesian Economics Since 1936, Cheltenham: Edward Elgar.

Kirman, A. (1989): The intrinsic limits of modern economic theory: the emperor has no clothes, in: Economic Journal, Supplement, 99(395), I26-39.

Kirman, A. (1992): Whom or what does the representative individual represent?, in: Journal of Economic Perspectives, 6(2), $117-136$.

Koopmans, T. (1957): Three Essays on the State of Economic Science, London: McGraw-Hill.

Kriesler, P. (1992): Answers for Steedman, in: Review of Political Economy, 4(2), 163-170.

Laffond, J.-J., Laroque G. (1976): Existence d'un équilibre général de concurrence imparfaite: Une introduction, in: Econometrica, 44(2), 283-294.

Lavoie, M. (1992): Foundations of Post-Keynesian Economic Analysis, Cheltenham: Edward Elgar.

Lee, F. (1998): Post Keynesian Price Theory, Cambridge: Cambridge University Press.

Lee, F., Earl, P. (1993): The Economics of Competitive Enterprise. Selected Essays of P.W.S. Andrews, Cheltenham: Edward Elgar.

Mainwaring, L. (1992): Steedman's critique: a tentative response from a tentative Kaleckian, in: Review of Political Economy, 4(2), I7I-177.

Marshall, A. (1920) [1949]: Principles of Economics, $8^{\text {th }}$ revised edition, London: Macmillan.

Pasinetti, L.L. (1988): Sraffa on income distribution, in: Cambridge Journal of Economics, I2, $\mathrm{I} 35-\mathrm{I} 38$.

Ritzvi, S.A.T. (1994): The microfoundations project in general equilibrium theory, in: Cambridge Journal of Economics, I8, 357-377. 
Romer, P. (1986): Increasing returns and long-run growth, in: Journal of Political Economy, 94(5), IOO2-I037.

Romer, P. (1990): Endogenous technological change, in: Journal of Political Economy, 98(5), 7I-IO3.

Roncaglia, A. (1978): Sraffa and the Theory of Prices, Chichester: Wiley.

Sala-i-Martin, X. (1997): I just ran two million regressions, in: American Economic Review. Papers and Proceedings, 87(2), I78-183.

Sardoni, C., Kriesler, P. (eds.) (1999): Keynes, Post-Keynesianism and Political Economy: Essays in Honour of Geoff Harcourt, Vol. 3, New York/London: Routledge.

Sawyer, M. (1992): Questions for Kaleckians: A response, in: Review of Political Economy, 4(2), I52-162.

Sawyer, M. (1995): Unemployment, Imperfect Competition and Macroeconomics, Cheltenham: Edward Elgar.

Semmler, W. (1984): Competition, Monopoly and Differential Profit Rates, New York: Columbia University Press.

Setterfield, M. (1997): Rapid Growth and Relative Decline, London and Basingstoke: Macmillan. Solow, R. (I99I): New directions in growth theory, in: Gahlen, B. (ed.), Wachstumstheorie und Wachstumspolitik. Ein Neuer Anlauf, Tübingen: Mohr.

Solow, R. (1997): Learning from ,Learning by doing`. Lessons for Economic Growth, Stanford/ California: Stanford University Press.

Sonnenschein, H. (1972): Market excess demand functions, in: Econometrica, 40(3), 549-563.

Sraffa, P. (1925) [1998]: Sulle relazioni fra costo e quantità prodotta, in: Annali di Economia, 2, 277-328. English translation by John Eatwell and Alessandro Roncaglia, in: Pasinetti, L.L. (ed.), Italian Economic Papers, vol. 3, Bologna: Il Mulino I998 and Oxford: Oxford University Press 1998, 323-363.

Sraffa, P. (1926): The laws of returns under competitive conditions, in: Economic Journal, 36 , $535-550$.

Sraffa, P. (1960): Production of Commodities by Means of Commodities, Cambridge: Cambridge University Press.

Steedman, I. (1990): Questions and suggestions re gravitation, in: Political Economy. Studies in the Surplus Approach, 6(I-2), 69-72.

Steedman, I. (1992): Questions for Kaleckians, in: Review of Political Economy, 4(2), I25-I5I.

Steedman, I. (1993): Points for Kaleckians, in: Review of Political Economy, 5(I), II3-II6.

Steindl, J. (1993): Steedman versus Kalecki, in: Review of Political Economy, 5(I), II9-I23.

Sutton, J. (1990): Explaining everything, explaining nothing? Gametheoretic models in industrial economics, in: European Economic Review, 34, 505-512.

Sylos Labini, P. (I97I): La théorie des prix en régime d'oligopole et la théorie du développement, in: Revue d'Economie Politique, 8I(2), 244-272.

Sylos Labini. P. (1969): Oligopoly and Technical Progress, Revised Edition, Cambridge, Massachusetts: Harvard University Press.

Toner, P. (1999): Main Currents in Cumulative Causation: The Dynamics of Growth and Development, London/Basingstoke: Macmillan. 
Triffin R. (1940): Monopolistic Competition and General Equilibrium Theory, Cambridge/Mass.: Harvard University Press.

Vives, X. (200I): Oligopoly Pricing. Old Ideas and New Tools, Cambridge/Mass./London: The MIT Press.

Walliser, B. (2006): Justifications of game equilibrium notions, in: Arena, R., Festre, A. (eds.), Knowledge, Beliefs and Economics, Cheltenham: Edward Elgar, 83-106.

Wood, A. (1975): The Theory of Profits, Cambridge: Cambridge University Press.

Young, A.A. (I9I3): Pigou's wealth and welfare, in: Quarterly Journal of Economics, 27(3), 678-686.

Young, A.A. (1928): Increasing returns and economic progress, in: Economic Journal, 38, 527-542.

Young, A.A. (1990): Nicholas Kaldor's notes on Allyn Young's LSE lectures, 1927-29, in: Journal of Economic Studies, I7(3/4), I8-II4. 